Original Research Articles

\title{
The Influence of Mineral Fertilizers on the Chemical Composition of Verdurous Masses of Forder Crops
}

\author{
${ }^{1}$ Nurali S. Nurgaliyev, ${ }^{1}$ Serik Z. Bekzhanov, \\ ${ }^{1}$ Ibadulla A. Tautenov, ${ }^{1}$ Ainur A. Nurgaliyeva and ${ }^{2}$ Murat O. Nassimov \\ ${ }^{1}$ Korkyt Ata Kyzylorda State University, Kyzylorda, Kazakhstan \\ ${ }^{2}$ University "Bolashak", Kyzylorda, Kazakhstan
}

Article history

Received: 27-8-2015

Revised: $10-9-2015$

Accepted: $21-9-2015$

Corresponding Author:

Murat O. Nassimov

University "Bolashak"

Kyzylorda, Kazakhstan

Email: nasimov_m@mail.ru

\begin{abstract}
This article presents the results of sorghum and pearl millet studies conducted in order to develop the technology of their cultivation as a new forage crops for livestock in arid areas of Kazakhstan. The article presents data on the effect of seeding rates and term of sowing on seeds germination and survival of plants and a crop of verdurous masses of sorghum and pearl millet against the background of watering. The optimal seeding rate and sowing of sorghum and pearl millet in saline soils of rice irrigation systems are determined in terms of the ecological crisis in Aral Sea region, Kazakhstan.
\end{abstract}

Keywords: Sorghum, Pearl Millet (African millet), Seeding Rate, Seed, Term of Sowing, Verdurous Masses, Crop-Producing Power

\section{Introduction}

From the mid-1960s to the end of the 1970s new technologies and innovations, including the choice of semi-dwarf cultivars, split dressings of nitrogen, use of growth retardants and the use of systemic fungicides and insecticides were introduced in wheat cropping systems to enhance yields.

Now the assessment of power and agronomical efficiency of use of fertilizers is widespread. The complex assessment taking into account their agronomical and power efficiency is important for development of more productive, less energy-intensive receptions and technologies of use of fertilizers.

Big relevance is gained by a problem of decrease in costs of energy of production of agricultural production. It is important to develop and use energy saving technologies at which less energy is spent for production of agricultural production. Increasing costs of production and use of fertilizers more and more actual there is a question of efficiency of their application.

Use of mineral fertilizers can be one of decisions, the problem which is particularly acute for agriculture power and resource-saving, economically safe use of fertilizers. The analysis of expenses of energy at cultivation African millet on grain by results of our researches showed increase of growth of productivity of the African millet in process of increase of a dose of fertilizers.
Climate change, degradation of soil and natural resources, desertification, scarcity of water and droughts threaten the food security of Kazakhstan. One of the major problems for feed and crop production is global warming, resulting in consequences for agriculture in the projected climate change is to increase the dryness due to increased air temperature, deterioration of heat and moisture in the plants during their growing season in the modern terms of sowing, decreasing the volume of snow by increasing winter temperatures, increasing soil salinity (Lie, 2012; Akhanov and Karazhan, 2001).

The rapid implementation in the agricultural production of drought-resistant, high-yield crops that can be grown throughout the country, especially in marginal and saline lands, is the most effective solution to the problem (Maksimov, 1948; Medvedev, 2004).

In conditions of global warming it is necessary to introduce crops and varieties that use carbon dioxide atmosphere most effectively. These are cultures with $\mathrm{C}_{4}$ type photosynthesis and they are capable of forming optimal vegetation on saline soils in arid conditions, where it is known as the increased emission of carbon dioxide into the atmosphere (Mikhalev et al., 2007; Monova, 1965).

These salt-tolerant and drought-resistant cultures of $\mathrm{C}_{4}$ type photosynthesis are sorghum and pearl millet.

The elements of sorghum and pearl millet cultivation technology were studied to solve the problem of efficient use of saline irrigated land; livestock provision of succulent feed and hay. 
Considering sorghum and pearl millet as a living plant organism, it is necessary to know their biological features. It is impossible to build the right agricultural techniques and to obtain a high yield without knowledge of the biology, life characteristics of culture, its requirements for living conditions and the time of cultivation. Harvest is always higher in the practice of agricultural industry, which is combined with the biological requirements of culture techniques of farming (Dzhamantikov, 2009; Varadinov and Vilichku, 1989).

African millet and sorghum are heat-loving and quite drought-resistant plants. The growing season lasts for 4-5 months. Moisture, heat and oxygen are necessary for germination, wherein it absorbs $23-25 \%$ of water of its weight.

Germination begins at a temperature of $14-15^{\circ} \mathrm{C}$. The best conditions for germination and emergence of seedlings is at soil temperature of $18-22^{\circ} \mathrm{C}$ and humidity over $20 \%$.

African millet and sorghum are drought-resistant crops. Water saving is due to the stomata occlusion in the heat; tissues that conduct water from the roots to the leaves is developed better in pearl millet than in other plants, so in the dry season it is abundantly supplied with water, because the roots "exhaust" the moisture from the dry soil (Kirillov, 1968; 1971; Lisov, 1968).

African millet and sorghum may make a temporary dewatering of tissue without compromising the harvest. In hot weather leaf stomata are closed and the evaporation stops.

African millet and sorghum respond very well to make it into the soil under crops of organic and mineral fertilizers and give an increase in yield of 8-10 C/ha.

Thus, it is possible to increase economic stability. The economic sustainability of the crop can be achieved provided business choices are reoriented, by adopting strategies of both horizontal and vertical integration. Economic sustainability is the prerequisite for survival of any production process over time and, therefore, of any economic activity able to create opportunities for both employment and income (Sgroi et al., 2014; Spiertz, 2013).

It was found that $3 \mathrm{~kg}$ of nitrogen, $1,4 \mathrm{~kg}$ of phosphorus $\left(\mathrm{P}_{2} \mathrm{O}_{5}\right), 3,5 \mathrm{~kg}$ of potassium $\left(\mathrm{K}_{2} 0\right)$ and $1 \mathrm{~kg}$ of lime are consumed for each quintal of grain and two hundredweight of millet straw plants.

Millet uses more potassium and lime compared with wheat; in comparison with corn - a little more phosphorus; about 30 grams of ash constituent and nitrogen are required for kilogram formation of air-dry mass of millet and corn, whereas only 23 grams for wheat.

\section{Materials and Methods}

Field studies were conducted in the fields of the Kazakh Research Institute of Rice, which is in the middle region of Kyzylorda. The climate of area is sharply continental, accumulated temperatures above $+15^{\circ} \mathrm{C}$ is $33^{\circ} \mathrm{C}$. The total atmospheric precipitation is 90 $140 \mathrm{~mm}$ for the year, most of which is in the fall and spring. Climatic indicators of growing seasons during the years of the experiments are shown in Table 1.

The studies were conducted on the territory which relates average economic zone of Kyzylorda region. In the context of the zone only irrigated agriculture is developed, so precipitation does not particularly affect the growth and development of plants. In spring 2013 it was warm and dry compared to other years. The average air temperature in the spring was equal to $15,3^{\circ} \mathrm{C}$ and then it was higher to $3,2^{\circ} \mathrm{C}$ by mean annual indicator. Precipitation was little $39,0 \mathrm{~mm}$ and it is below $10 \mathrm{~mm}$ mean annual indicator of precipitation (Matarueva and Vinogradov, 2002; Minina, 1972).

The summer months (June, July and August) were characterized by very hot and dry weather. Since midJune, the daily average temperature of air was at the level of mean annual indicator and daytime reached up to $42,1^{\circ} \mathrm{C}$ maximum.

In summer months, precipitation was $14,0 \mathrm{~mm}$ and it is lower to $30 \%$ at average indicator of $20 \mathrm{~mm}$ (Table 1).

In 2014 there were anomalies in weather-climatic conditions. In May, the lowest temperature of the air temperature $\left(6,3^{\circ} \mathrm{C}\right)$ was on 20 th May, the highest temperature $\left(40,1^{\circ} \mathrm{C}\right)$ was on 28 May. Month of May was characterized by a complete lack of rainfall and 11 $\mathrm{mm}$ of rain, according to Table 1 , have fallen only once on May 31 and also with the shock in air temperature, so the difference between day and night temperatures ranged from 14,0 to $20,0^{\circ} \mathrm{C}$. In June, the air temperature deviation from the norm was $+2,6^{\circ} \mathrm{C}$ with the full absence of precipitation. The highest air temperature $\left(42,8^{\circ} \mathrm{C}\right)$ was on 21 June. Such climatic conditions contributed to the rapid passage of the fractional development of the studied crops (Kondratov, 2002; Prosvirkina, 1998).

Soil of experimental area is meadow marsh, cultivated, irrigated typical soil of rice systems. The content of total humus in the soil ranged between $0,7-$ $0,9 \%$, which is indicative of its low fertility. The content of movable phosphorus varies from low $(12-15 \mathrm{mg} / \mathrm{kg}$ ) to medium. Soil provision with exchange potassium is also weak. The degree of salinity is from medium to high. The amount of water-soluble salt of dense residue varied from $1,35 \%$ to $1,58 \%$. The salinity is chloridesulfate (Table 2).

The soil rice systems of Aral Sea region, Kazakhstan have low fertility, so any crops grown in the region responds well to the introduction of nitrogen and phosphate fertilizers. 
Table 1. Agro-climatic indicator (meteorological station data Kyzylorda, 2013-2014)

$$
\text { Years of study }
$$

\begin{tabular}{|c|c|c|c|c|c|c|}
\hline \multirow[b]{3}{*}{ Months } & \multirow{2}{*}{\multicolumn{2}{|c|}{ Mean annual significance }} & \\
\hline & & & \multicolumn{2}{|l|}{2013} & \multicolumn{2}{|l|}{2014} \\
\hline & Preci-pitatio (mm) & Air t $\left({ }^{\circ} \mathrm{C}\right)$ & Preci-pitatio (mm) & $\operatorname{Air} \mathrm{t}\left({ }^{\circ} \mathrm{C}\right)$ & Preci-pitatio (mm) & Air $\mathrm{t}\left({ }^{\circ} \mathrm{C}\right)$ \\
\hline Apr & 16 & 13,3 & 23 & 15,2 & 24 & 10,6 \\
\hline May & 16 & 20,3 & 9 & 21,9 & 11 & 24,1 \\
\hline June & 10 & 26,1 & 10 & 26,7 & 0 & 28,7 \\
\hline July & 6 & 27,8 & 1 & 28,6 & 0 & 27,1 \\
\hline Aug & 4 & 25,7 & 3 & 27,8 & 0 & 28,0 \\
\hline Sept & 4 & 18,6 & 3 & 19,2 & 3 & 18,5 \\
\hline
\end{tabular}

Table 2. Soil characteristics of the experimental area

\begin{tabular}{lll}
\hline Reading & Unit of measure & Substance \\
\hline $\begin{array}{l}\text { pH salt extraction } \\
\text { Moving phosphorus }\end{array}$ & $\mathrm{pH}$ & $7,7-7,9$ \\
$\left(\mathrm{P}_{2} \mathrm{O}_{5}\right)$ Machigin & $\mathrm{mg} / \mathrm{kg}$ & $12-15$ \\
$\begin{array}{l}\text { Movable potassium } \\
\left(\mathrm{K}_{2} \mathrm{O}\right) \text { at Machigin }\end{array}$ & $\mathrm{mg} / \mathrm{kg}$ & $120-140$ \\
Nitrates & $\mathrm{mg} / \mathrm{kg}$ & \\
Chloride & $\mathbf{\%}$ & $13-15,3$ \\
Sulfates soluble & $\mathrm{mg} / \mathrm{kg}$ & 0,041 \\
in terms of sulfur & & $340-550$ \\
Humus & $\mathbf{\%}$ & \\
\hline
\end{tabular}

Circuit of field experiment to study the effect of fertilizers on productivity and quality of sorghum and pearl millet consisted of four options:

- $\mathrm{N}_{0} \mathrm{P}_{0}$

$\mathrm{N}_{60} \mathrm{P}_{60}$ - before sowing

$\mathrm{N}_{120} \mathrm{P}_{60}$ - before planting

$\mathrm{N}_{60} \mathrm{P}_{60}$ - before sowing $+\mathrm{N}_{60}$ in tillering

The Uzbek breeding varieties, mid-ripening variety of sorghum Uzbekistanskaya 18 and early ripening variety of African millet Hashaki 1 are used in the experiment.

The research was carried out by conventional certified methods. Modern methods of chemical analysis were selected to provide agrochemical analyzes of soil, plants and water and the composition of the salts in aqueous extracts.

\section{Results}

Soil fertility and fertilizer usage at a greater extent affect the chemical composition and quality of plant products.

The data in Table 3 show that the use of mineral nitrogen and phosphate fertilizers helped to improve the chemical composition of the verdurous mass of the African millet. Nutritious carry-over determination of African millet plants at the heading stage showed that the fertilizer application of nitrogen-phosphorus increased the nitrogen, phosphorus and potassium and calcium carry-over.

$\mathrm{N}_{60} \quad \mathrm{P}_{60}$ application increased not only nitrogen and phosphorus carry-over, but also potassium and calcium (Table 3). The next version $\left(\mathrm{N}_{120} \mathrm{P}_{60}\right)$ significantly influenced the nitrogen increasing it by almost $10 \%$ and the remaining elements changed upward slightly. The high nitrogen in the verdurous masses of the African millet was observed with the introduction of $\mathrm{N}_{60} \mathrm{P}_{60}$ before sowing and $\mathrm{N}_{60}$ in extra nutrition in the tillering phase. Thus the nitrogen was increased by $15 \%$ compared with the controlled version of plants.

Pearl millet is cultivated for not only grain but also verdurous masses, which is of great importance for animal fodder (Rytova, 1976).

Our research has shown that the use of fertilizers for African millet provides a significant increase in yield and improves the quality, which is the nutritional value of verdurous masses (Table 4).

The protein substance depends on the dose of nitrogen fertilizer, at a dose of $\mathrm{N}_{60} \mathrm{P}_{60}$ it amounted to $12.6 \%$, with $\mathrm{N}_{120} \mathrm{P}_{60}$ carry-over it rose by almost $2 \%$ and amounted to $14.35 \%$. Applying a half dose of nitrogen fertilizer contributed to increase the protein substance to $0.3 \%$. The fat substance in the verdurous masses is also increased by the nitrogen and phosphate fertilizers carryover (Table 4). If the control variant in the verdurous masses of millet at the heading stage fat content was $1,94 \%$, then $\mathrm{N}_{60} \mathrm{P}_{60}$ carry-over was $2,03 \%, \mathrm{~N}_{120} \mathrm{P}_{60}$ addition was $2,06 \%$, but at repeated use of nitrogen 60 $\mathrm{kg} / \mathrm{ha}$ of fat substance increased to $2,08 \%$.

Also there was an increase in the ash content of 7,8\% to $8,55 \%$. Nitrogen-phosphorus fertilizers carry-over reduced ash substance up to $24 \%$, while its substance in the control variant is $24,9 \%$.

Also there was a marked decrease in the substance of nitrogen-free extractives with the nitrogen and phosphorus fertilizers carry-over by $40,3 \%$ in the control variant up to $33,1-33,4 \%$ with $\mathrm{N}_{120} \mathrm{P}_{60}$ carry-over.

The study of the chemical composition of the verdurous masses of sorghum showed that morphological fractions of plant substances are different (Table 5). 
Nurali S. Nurgaliyev et al. / American Journal of Agricultural and Biological Sciences 2015, 10 (3): 137.143 DOI: 10.3844/ajabssp.2015.137.143

Table 3. The influence of fertilizers on the chemical composition of the verdurous masses of African millet at the heading stage (in $\%, 2$ years average)

\begin{tabular}{lllr}
\hline & Nutrition elements & & \\
Experiment & - & & \\
version & $\mathrm{N}$ & $\mathrm{P}_{2} \mathrm{O}_{5}$ & $\mathrm{~K}$ \\
\hline Control & 1,99 & 0,17 & $\mathrm{C}$ \\
$\mathrm{N}_{60} \mathrm{P}_{60}$ & 2,04 & 0,21 & 1,35 \\
$\mathrm{~N}_{120} \mathrm{P}_{60}$ & 2,21 & 0,23 & 1,43 \\
$\mathrm{~N}_{60} \mathrm{P}_{60}+\mathrm{N}_{60}$ & 2,30 & 0,23 & 1,45 \\
\hline
\end{tabular}

Table 4. The influence of fertilizers on the quality of the verdurous masses of pearl millet (heading stage, $\%, 2$ years average)

\begin{tabular}{|c|c|c|c|c|c|}
\hline \multirow{2}{*}{$\begin{array}{l}\text { Experiment } \\
\text { version }\end{array}$} & \multicolumn{5}{|c|}{ Substances } \\
\hline & Protein & Fat & Cellulose & Ash & Biologically effective substance \\
\hline$\overline{\text { Control }}$ & 12,4 & 1,94 & 24,9 & 7,80 & 40,3 \\
\hline $\mathrm{N}_{60} \mathrm{P}_{60}$ & 12,6 & 2,03 & 24,7 & 7,95 & 39,1 \\
\hline $\mathrm{N}_{120} \mathrm{P}_{60}$ & 14,35 & 2,06 & 24,3 & 8,52 & 33,4 \\
\hline $\mathrm{N}_{60} \mathrm{P}_{60}+\mathrm{N}_{60}$ & 14,63 & 2,08 & 24,0 & 8,55 & 33,1 \\
\hline
\end{tabular}

Table 5. Chemical composition of hay sorghum varieties Uzbekistan's 18 by morphological fractions

\begin{tabular}{|c|c|c|c|c|c|c|c|}
\hline \multirow[b]{2}{*}{$\begin{array}{l}\text { Morphological } \\
\text { fractions }\end{array}$} & \multirow[b]{2}{*}{$\begin{array}{l}\text { Correlation } \\
\text { of fraction }\end{array}$} & \multicolumn{6}{|c|}{ Chemical composition $(\%)$} \\
\hline & & $\begin{array}{l}\text { Absorbed } \\
\text { moisture }\end{array}$ & Protein & Fat & Cellulose & Ash & $\begin{array}{l}\text { Biologically } \\
\text { effective substance }\end{array}$ \\
\hline Body & 65,9 & 13,8 & 13,0 & 1,2 & 17,7 & 4,5 & 0,2 \\
\hline Leaves & 21,2 & 7,8 & 11,0 & 0,7 & 4,5 & 2,5 & 3,5 \\
\hline Head & 13,2 & 10,2 & 5,4 & 0,7 & 4,0 & 2,0 & 7,7 \\
\hline
\end{tabular}

Table 6. The influence of fertilizers on the quality of the verdurous masses of sorghum (heading stage $\%, 2$ years average)

\begin{tabular}{|c|c|c|c|c|c|}
\hline \multirow{2}{*}{$\begin{array}{l}\text { Experiment } \\
\text { version }\end{array}$} & \multicolumn{5}{|c|}{ Substances } \\
\hline & Protein & Fat & Cellulose & Ash & Biologically effective substance \\
\hline Control & 11,4 & 0,8 & 13,9 & 4,5 & 42,7 \\
\hline $\mathrm{N}_{60} \mathrm{P}_{60}$ & 12,5 & 0,9 & 14,3 & 4,4 & 40,9 \\
\hline $\mathrm{N}_{120} \mathrm{P}_{60}$ & 13,2 & 0,9 & 14,4 & 4,3 & 40,6 \\
\hline $\mathrm{N}_{60} \mathrm{P}_{60}+\mathrm{N}_{60}$ & 13,7 & 0,9 & 14,2 & 4,3 & 40,3 \\
\hline
\end{tabular}

Table 7. Dynamics of the plant growth depending on the fertilizer

\begin{tabular}{|c|c|c|c|c|}
\hline \multirow[b]{2}{*}{ Variants } & \multicolumn{4}{|c|}{ Plant height $(\mathrm{cm})$} \\
\hline & Tillering & Paniculation & Flowering & Complete ripeness \\
\hline Control & 82 & 213 & 265 & 234 \\
\hline N90P90K90 & 92 & 230 & 271 & 245 \\
\hline N1soP1 soKi so & 161 & 290 & 334 & 317 \\
\hline The manure & & & & \\
\hline (30 t/ha) & 101 & 278 & 297 & 269 \\
\hline Zeolite $(2,5 \mathrm{t} / \mathrm{ha})$ & 87 & 232 & 287 & 268 \\
\hline Zeolite $(5 \mathrm{t} / \mathrm{ha})$ & 148 & 243 & 303 & 291 \\
\hline $\begin{array}{l}\text { N90P90K } 90+\text { preplant } \\
\text { processing of seeds with } \\
\text { potassium humate }\end{array}$ & 115 & 239 & 290 & 265 \\
\hline $\begin{array}{l}\text { N90P90K } 90+\text { extra } \\
\text { nutrition with potassium } \\
\text { humate }\end{array}$ & 111 & 220 & 272 & 254 \\
\hline $\begin{array}{l}\text { N90P90K90 + preplant } \\
\text { processing of seeds }+ \text { extra } \\
\text { nutrition with potassium humate }\end{array}$ & 128 & 260 & 315 & 302 \\
\hline N90P90K90 + cerium (IV) & 119 & 259 & 313 & 282 \\
\hline
\end{tabular}




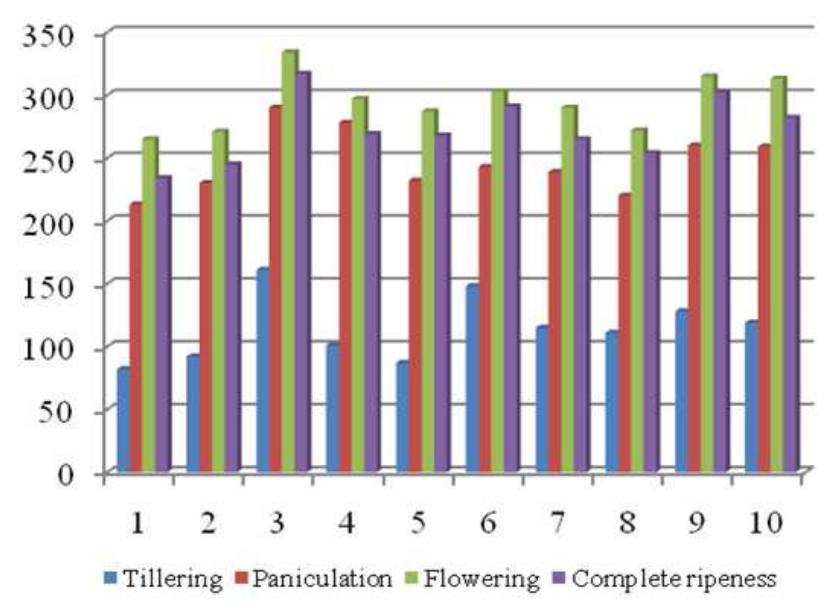

Fig. 1. Dynamics of a pearl millet plant growth depending on fertilizers

According to gravimetric analysis (Table 5) the verdurous masses contain an average of $65,9 \%$ of stems, poorly eaten parts, which require additional grinding and preparation for feeding animals and eatable parts of hay $34,1 \%$. The chemical composition of the verdurous masses of sorghum by morphological fractions indicates that the chemical composition of stems slightly cede to leaves and heads.

Chemical composition of a whole plant was determined while studying the influence of doses of nitrogenphosphorus fertilizer on the chemical composition of the verdurous masses of sorghum (Table 6).

\section{Discussion}

The studies have shown that the protein substance in the verdurous masses in the cases of fertilizers was higher and with improved nitrogen nutrition of plants it increased to $13.7 \%$ for the index in the control variant $11.4 \%$. Fertilizer application had no significant effect on fat substance; it varied between $0.8-0.9 \%$ in all experimental variants. Cellulose substance in verdurous masses increased from 13.9 to $14.4 \%$ with the yield increase on the nitrogen-phosphorus fertilizer variants. There were decrease nitrogen-free extractives from 42.7 to $40.3 \%$ on versions with fertilizers.

Great importance of fertilizers in intensive agriculture and all agricultural production is confirmed by the practice of agriculture. The share of fertilizers accounts for $40-50 \%$ amount of growth in grain crops productivity and $50-70 \%$ is hay of perennial meadow and cropped grasses in our country (Maisuryan, 1960; Samonova, 1992).

We regulate nutrient regime of the soil with fertilizer, improving its biological and physical properties in order to obtain high and stable yields. Fertilizers have a great impact on product quality: protein substance in grain, starch in potato tubers and vitamins in fodder increases, which affect the productivity of the animals; output of grain, fodder and other products increase from 1 hectare.

Organic fertilizer carry-over enriches the soil with organic substance, contributes to the accumulation of humus and soil protection from erosion.

The millet fertilizer system consists of application by under-winter ploughing of manure or compost along with the phosphate and potash fertilizers (to $90 \mathrm{~kg}$ P2O5 and $60 \mathrm{~kg} \mathrm{K2O}$ ); nitrogen fertilizer (to $60 \mathrm{~kg} \mathrm{~N}$ ) makes presowing cultivation.

At sowing application of $50 \mathrm{~kg} / \mathrm{ha}$ of granulated superphosphate in rows gives good effect. It is desirable to feed with local organic (4 tons of liquid manure per ha) or mineral fertilizers $(15-20 \mathrm{~kg}$ of nitrogen, phosphorus and potassium) during the tillering and stalkshooting. Pearl millet in rotation with guar is widely cultivated in the state of Haryana, in the arid zone of the north-west of the country. In the 1990-95's on sierozem $(\mathrm{pH} 8,3)$, reaction of millet to the application of up to 60 $\mathrm{kg} / \mathrm{ha}$ of nitrogen (urea) and triple superphosphate 30 $\mathrm{kg} / \mathrm{ha} \mathrm{N}$ and $60 \mathrm{~kg} / \mathrm{ha} \mathrm{P} 2 \mathrm{O} 5$ was studied with weak nitrogen and moderately secure phosphor. On dose of nitrogen basically fertilizers and extra nutrition in a phase of stalk-shooting (under favorable soil moisture) was applied under the millet. Seeding rate of pearl millet and sorghum is an average $5 \mathrm{~kg} / \mathrm{ha}$ and width space between rows is $45 \mathrm{~cm}$. Collection of forage body (leaves and heads) of millet increased with augmentation doses of nitrogen and phosphate fertilizers. Our field and vegetation experiments, carried out in different areas with different crops, showed the effect of applied potassium on the yield depending on the interaction with other elements.

At low doses of potassium in the nutrient medium in vegetation experiment corn productivity is above under application of NH4-N in a dose of $80 \sim 160 \mathrm{mln} 1 \mathrm{~N}$, at a dose of $320 \mathrm{mln} 1 \mathrm{~N}$ in the form of NO3-N. In vegetation experiments with pearl millet it was found that only high doses of potassium without augmentation of phosphorus does not increase yields: on version of ROKO and ROK200 obtained 2 g/pot grains, while simultaneously augmentation doses of potassium and phosphorus are 8 and $14 \mathrm{~g} /$ pot.

Nitrogen application increased collection of bodies in dry years by $33 \%$ and in normal years with precipitation by $100 \%$.

Nitrogen fertilizer has doubled the number of head/house at low density and normal precipitation. It is recommended to cultivate millet at 15-20 thousand houses/ha and N30 in 2 divided doses.

Abdel Gadir W.S., Adam S.E. and others conducted long-term experiments in the rotation: pearl millet-wheat. Fertilizers were applied in doses of N60 and $120, \mathrm{P}-0,30$ and $60, \mathrm{~K}-60 \mathrm{~kg} / \mathrm{ha}$. The soil is loam with exchangeable potassium content of 620 
$\mathrm{kg} / \mathrm{ha}$ of potassium and nonexchangable $5870 \mathrm{~kg} / \mathrm{ha}$ (Abdel Gadir et al., 2000).

The content of exchangeable potassium in the soil was decreased after 12 years of experience to $200 \mathrm{~kg} / \mathrm{ha}$. Carry-over of potassium with crops did not depend on its level in the soil. Crops harvest increased with augmentation doses of nitrogen and phosphate fertilizers, but not on the dose of potassium fertilizers.

The experiment during the rainy season of 1997 on studying the influence of 7 concentrations of boron on pearl millet showed that the boron concentration of 0.33 $\mathrm{mg} / \mathrm{L}$ had an increase of head (69.8 gram per plant), grain yield of 50.9 gram per plant and a mass of 100 grains and 117.1 gram per plant biomass.

Also field studies were conducted with the aim to maximize the yield of millet in dry farming during the rainy season of 1985-86. Basic phosphorus dose of $17 \mathrm{~kg}$ and $25 \mathrm{~kg} / \mathrm{ha}$ was applied to plots before sowing. Nitrogen is introduced in the form of urea at planting time. Applying fertilizer increased the yield of leavehead mass and grain.

The first phase of African millet growth should be held in good security of phosphorus and potassium and applying these fertilizers plants are affected by low temperatures, soil and air drought. Practice confirmed that the plants with a sufficient stock of food varlotzed per gram of produced dry matter less moisture than with the shortage of food.

It is useful to enhance nitrogen nutrition with the appearance of 4-5 leaves, so that the plant can develop a powerful leaf surface. Increased dose of phosphorus forwards ripening and improves grain forming during the second half of the vegetation.

The growing season of African millet and sorghum depends on the cultivar and growing conditions. The growing season of African millet and sorghum are longer in the wet summers with low temperature than in dry years with a high temperature. The duration of the millet vegetation is strongly influenced by weather conditions. It increases in prolonged cold spring.

Dry spring also delays the ripening period, along with the period of millet and sorghum development is prolonged from coming-up to the paniculation. Wet and warm spring shortens the growing season, which is largely determined by the duration of daylight (Tsugkiev and Tyutyunnikov, 1996).

Pearl millet and sorghum are short-day plants, so they develop in the south and give a normal harvest in a shorter period than in the north. African millet and sorghum take several age-specific changes from comingup to ripening, or phase of development. They are heatloving crops and this attribute is associated with this well-known agronomic rule: sow it only in warm soil.

As the growth rate and the dry weight production during the vegetation indicate the formation of the crop, it is necessary to carry out visual and biometric monitoring of the dynamics of growth processes.

As it can be seen from Table 3, in the control and fertilized variants, while growing millet and sorghum for soiling food and corn shoots emerged in 10 days and fertilized variants in 9 days.

African millet and sorghum are plants that are quite demanding to growth factors and development. They require different amounts of heat and moisture from the soil and climatic conditions throughout the growing season, from seed germination and ending with the formation of a new grain (Motovilova, 1994).

The highest growth and the accumulation of verdurous masses are shown in Table 4. The pearl millet and sorghum are growing relatively slowly at the beginning of the growing season to tillering. In the sequel, growing processes are forwarded and in fertilized variants they end earlier than in unfertilized. Biometric observations have revealed significant changes in plant growth and development in making the traditional and non-traditional fertilizers.

Our research has shown (Fig. 1 and Table 7), that on the average in the control in the tillering phase of plants millet and sorghum had a height of $82 \mathrm{~cm}$, for the second time of observation plant height reached $213 \mathrm{~cm}$. In the flowering stage the maximum plant height reached $265 \mathrm{~cm}$.

\section{Conclusion}

Application of mineral nitrogen and phosphate fertilizers helped to improve the chemical composition of the verdurous masses of the plant African millet and increased carry-over of not only nitrogen and phosphorus, but also potassium and calcium.

The content of protein depended on the dose of nitrogen fertilizer, with a differentiated application $14,63 \%$ of the maximum protein content was observed, which is more by $2,2 \%$ than in the control variant.

The study of the nitrogen-phosphorus fertilizer influence on the chemical composition of verdurous masses of sorghum showed that variants of fertilizer due to improved nitrogen supply increased protein and fiber content, while reducing the content of nitrogen-free extractives.

On the basis of these studies we can conclude that the verdurous masses of African millet and sorghum are heavy roughage feeders and can be an alternative source of food and fodder reserve capacity of livestock in arid areas.

Dynamics of plant growth is consistent with the dynamics of nutrients in the soil. Variants $\mathrm{Ni}_{80}$ Pi so Kiso, $\mathrm{N}_{90} \mathrm{P}_{90} \mathrm{~K}_{90}+$ preplant processing of seeds + extra nutrition with potassium humate, zeolite $5 \mathrm{t} / \mathrm{ha}, \mathrm{N}_{90} \mathrm{P}_{90} \mathrm{~K}_{90}+$ extra nutrition with sulfate cerium differ with taller plants. 


\section{Acknowledgment}

As a result of experiments, scientists found out that millet and a sorghum well grows new grades on strongly salted soils. It is possible to grow up on the degraded pastures in the desert. High quality of grain allows to use it as a forage for a small cattle during a lactation and also in poultry farming.

\section{Funding Information}

The experiments were supported by funding from the Kazakh research institute of rice growing of Zhakhayev, Kyzylorda city, Kazakhstan.

\section{Author's Contributions}

We certify that all persons who have made substantial contributions to the work reported in this manuscript.

Nurali S. Nurgaliyev, Serik Z. Bekzhanov and Ibadulla A. Tautenov: He conducted field researches, made the literary review, analyzed and interpreted the results and drew conclusions.

Ainur A. Nurgaliyeva: She edited tables and drawings, printed the text and wrote the conclusion accroding to tables.

Murat O. Nassimov: He carried out all technical and organizational works.

\section{Ethics}

The manuscript represents original and valid work and does not infringe or violate any copyright agreements or any other personal or proprietary rights and neither this manuscript nor one with substantially similar content has been published or is being considered for publication elsewhere; copies of closely related manuscripts are provided.

\section{References}

Abdel Gadir, W.S. and S.E. Adam, 2000. Effects of pearl millet (Pennisetum typhoides) and fermented and processed fermented millet on Nubian goats. Veterinary Human Toxicology, 42: 133-136. PMID: 10839314

Akhanov, ZH.U. and K.R. Karazhan, 2001. Optimizing the use of soil resources in the Aral Sea region of Kazakhstan under anthropogenic desertification. Scientific bases of Reproduction of Soil Fertility, Protection and Rational use of Soil in Kazakhstan, Almaty, pp: 154-157.

Dzhamantikov, Kh.D., 2009. Involvement of wastelands under cultivation in a paddy field of rice crop rotation soil in the Aral Sea region, Kazakhstan. Proceedings of the 12th International Scientific and Practical Conference, Agricultural Science and Agricultural Production of Kazakhstan, Siberia and Mongolia, Shymkent, Kazakhstan, pp: 74-77.
Kirillov, Y.I., 1968. Pearl millet. Kaynar, Almaty, pp: 54.

Kirillov, Y.I., 1971. Biology of sorghum and pearl millet flowering. Applied Botany Genetics Breeding.

Kondratov, A.G., 2002. Potassium humate-peaty liquid. Agrochemical Vestnik, 2: 40-41.

Lie, A.O., 2012. The current state of agriculture in Kazakhstan: Scientific bases of development of innovative rice in Kazakhstan and abroad. Proceedings of the International Scientific-Practical Conference, Kyzylorda, Kazakhstan.

Lisov, V.N., 1968. Millet. Kolos, Leningrad, pp: 224.

Maisuryan, N.A., 1960. Crop production. Selhozizdat, Moscow, pp: 428.

Maksimov, N.A., 1948. Plant Physiology. MoscowLeningrad, pp: 440.

Matarueva, I.A. and B.C. Vinogradov, 2002. Action of humate on complex "plants-microflora". Agrochemical Vestnik, 1: 15-16.

Medvedev, S.S., 2004. Plant Physiology. St. Petersburg University Publishing House, Saint Petersburg, pp: 336.

Mikhalev, S., N. Khokhlov and N. Lazarev, 2007. Provender milling with the basics of farming. KolosS, Moscow, pp: 368.

Minina, I.P., 1972. Meadow mixed grass crop. Kolos, Moscow.

Monova, E., 1965. Varieties of millet. Kolos, Moscow, pp: 287.

Motovilova, L.V., O.N. Berman and O.V. Skvortsov, 1994. Humates are clean stimulants of plant growth and development. Chemistry Agriculture, 5: 12-13.

Prosvirkina, A.G., 1988. Agrometeorological conditions of millet seed growth. Agricultural Meteorology, Gidrometeoizdat, Leningrad, pp: 279-315.

Rytova, N.G., 1976. Morphogenetical factors of limiting tillering grasses in vegetative phase. Botanical J., 12: $1670-1680$.

Samonova, O.A., 1992. Rare earth elements: Lanthanum, cerium, samarium, europium in the forest-steppe soils of the Volga Uplands. Pochvovedenie, 6: 44-46.

Sgroi, F., A.M. Di Trapani, R. Testa and S. Tudisca, 2014. Economic sustanaibility of early potato production in the mediterranean area. Am. J. Applied Sci., 11: 1598-1603. DOI: 10.3844 /ajassp.2014.1598.1603

Spiertz, H., 2013. Challenges for crop production research in improving land use, productivity and sustainability. Sustainability, 5: 1632-1644. DOI: $10.3390 /$ su5041632

Tsugkiev, B.G. and A.I. Tyutyunnikov, 1996. The chemical composition of non-traditional fodder and medicinal herbs. Rosselkhozakademiya, Moscow, pp: 135.

Varadinov, S.G. and L.V. Vilichku, 1989. A comparative study to identify the possibilities of using millet crops in the Kuban. Scientific Technical Bulletin VIR, 189: 63-66. 